\title{
Global medication waste management practices: challenges and opportunities in developing countries
}

\author{
Vipula R. Bataduwaarachchi*, Chamari L. Weeraratne
}

Department of Pharmacology and Pharmacy, Faculty of Medicine University of Colombo, PO Box 271, Kynsey Road, Colombo 8, Sri Lanka

Received: 06 October 2016 Accepted: 03 November 2016

*Correspondence to:

Dr. Vipula R.

Bataduwaarachchi,

Email: vipbat7@yahoo.com

Copyright: () the author(s), publisher and licensee Medip Academy. This is an openaccess article distributed under the terms of the Creative Commons Attribution NonCommercial License, which permits unrestricted noncommercial use, distribution, and reproduction in any medium, provided the original work is properly cited.

\begin{abstract}
Medication waste is synonymous with pharmaceutical waste, unused or expired medicines. Improper disposal of medication waste leads to serious personal and environmental health hazards. There were no established medication waste management programmes in most of the developing countries including Asia. Presence of unique socioeconomic problems in these counties makes the establishment of successful medication waste management programme a challenge. We reviewed the literature pertaining to the disposal of medication waste in different countries in order to understand the current status. We found that the medication waste disposal via normal sewage systems was the main method practiced in most of the countries and that the situation was much worse in developing countries. Return of unused medicines to pharmacies, which is considered to be the best method, was successfully practiced in some developed countries with established systems. Lack of proper mechanism to handle medication waste seems to be the main reason behind substandard medication waste management in developing countries. We propose a simple model for the disposal of medication waste taking into consideration the unique challenges and infra-structure issues in developing countries. International level policy and funding support, national level policy and unbiased financial allocations, institutional level comprehensive programmes according to the local requirements and most importantly the public support will make medication waste management programme a success. Furthermore, developing countries should join the on-going international forum on medication waste management. This short communication will be an eye opener for the academic key opinion leaders in developing countries to initiate medical waste management programmes in their countries.
\end{abstract}

Keywords: Developing countries, Medication waste, Pharmaceutical waste

\section{INTRODUCTION}

Medication waste is defined as items intended to be used in the diagnosis, treatment or prevention of diseases among humans or other animals and it is synonymous with pharmaceutical waste, unused or expired medicines. ${ }^{1}$ Improper disposal of medication waste leads to serious personal and environmental health hazards. ${ }^{2}$ Medication waste management is not given enough priority in developing countries and this short communication explores the opportunities for medication waste management in this setting.

Environmental pollution is a well-known consequence of improper medication waste management. The occurrence of pharmaceutically active compounds in the aquatic environment has been recognised as one of the serious and emerging problems in environmental chemistry. Most studies have given much emphasis on assessing the impact of ground water sources. In some investigations carried out in Europe and in the US, more than 80 pharmaceutical compounds and several drug metabolites have been detected in surface and ground water samples. The major concerns have been increased bacterial resistance to antibiotics and interference with growth and reproduction not only in human echo systems but also inside aquatic organisms such as fish and frogs. ${ }^{3}$ In the surface water, medication derived chemicals are present in lower concentrations posing environmental risks. However, targeted ecotoxicological studies are lacking almost entirely even in developed countries. ${ }^{4}$ It has been shown that impaired sexual development and increased feminisation of fish have occurred due to the presence of trace amount of oral contraceptive component, ethinyl oestradiol in rivers. ${ }^{5}$ According to some sources, landfill disposal of unused medicines reduces surface water releases. $^{6,7}$ 
Medicines thrown into garbage bins can be reached by children, animals and other individuals such as garbage collectors exposing them to serious health hazards including life threatening poisoning. Theoretically, medication waste with toxic, teratogenic or mutagenic potential can be accumulated in food chains and re-enter human biological systems. Repeated exposure to these substances can leads to chronic toxic effects or high dose short term exposures can leads to acute toxic effects among humans. These toxic effects will also affect useful microorganisms, insects, animals and plants.

The objective of this study was to develop insight regarding the current status of the world wide medication waste management with a view to develop a suitable model for medication waste management in developing countries considering their unique socio-economic problems.

\section{METHODS}

We conducted a comprehensive PubMed search for past 15 years on medication waste management. If the results had multiple studies from the same country conducted within a short period of time, we considered the most recent study for the analysis. When the articles had similar scope and details we selected the most informative article. We tried to include all geographical regions as much as possible to understand the variations of medication waste management practices. Data from the Asian countries were limited and incomplete.

\section{RESULTS}

The main method of medication waste disposal was via normal sewage systems or waste bins (Table 1). This showed the overall poor status of medication waste management practices worldwide. Sweden and Spain had the highest percentage of consumers returning unused medicines to pharmacies. However, some of the US and UK studies showed that the majority of consumers still practicing improper disposal via garbage bins.

We studied the common types of medicines disposed as medication waste. Studies conducted in Vienna and Oman had cardiovascular medicines as the highest percentage of medication waste comprising $18 \%$ and $24 \%$ of the samples respectively. Saudi Arabia had respiratory medicines as the highest percentage (16.8\%). In Mexico and Nigeria anti-inflammatory and analgesic medicines were the commonest, representing $16.11 \%$ and $18.6 \%$ of the samples respectively. Antibiotics were also found in higher percentages in most of the studies.

Assessment further showed that in Mexico, Germany and Vienna most of the medication waste comes from prescription only medicines in contrast to Nigeria and Kuwait where over the counter medications were the commonest (Figure 1). ${ }^{11,14,16-18}$ Table 2 summarise the reasons for medication waste production and the commonest cause was expiration of medicines in most of the studies.

In developed countries such as the United States medicine take-back programmes such as National prescription drug take-back events are used for safe disposal of unused medicines. These programmes are hosted by the US drug enforcement administration (DEA) and their local law enforcement agencies. ${ }^{20}$ Some DEAauthorised collection sites in the US also offer mail-back programmes or collection receptacles (drop boxes) to assist patients to safely dispose their unused medicines. ${ }^{21}$ California department of resources recycling and recovery provides a comprehensive programme of medicinal and pharmaceutical waste disposal which provides information on the banned medicines to be disposed via garbage as well as a list of pharmacies which collects unused medicines. ${ }^{1}$

Table 1: Medication waste disposal practices at household level in selected countries representing different regions.

\begin{tabular}{|c|c|c|c|c|}
\hline \multirow[b]{2}{*}{ Region } & \multirow[b]{2}{*}{$\begin{array}{l}\text { Country of the } \\
\text { study }\end{array}$} & \multicolumn{3}{|c|}{ Percentage $(\%)$ from the total sample using each disposal method } \\
\hline & & $\begin{array}{l}\text { Disposal via garbage/dustbin/ } \\
\text { sewage systems }\end{array}$ & $\begin{array}{l}\text { Flushed down the } \\
\text { toilet or sink }\end{array}$ & $\begin{array}{l}\text { Returned to a } \\
\text { pharmacy }\end{array}$ \\
\hline \multirow{4}{*}{ Europe } & Ireland $^{8}$ & 72 & - & - \\
\hline & United Kingdom $^{7}$ & 63.2 & 11.5 & 21.8 \\
\hline & Sweden $^{9}$ & - & - & 43 \\
\hline & Spain $^{10}$ & - & - & 84.6 \\
\hline Middle East & Kuwait $^{11}$ & 76.5 & - & - \\
\hline US & United States $^{12}$ & 54 & 35.4 & 1.4 \\
\hline \multirow{2}{*}{ Africa } & Ghana $^{13}$ & 75 & - & - \\
\hline & Nigeria $^{14}$ & 94.1 & - & - \\
\hline South Asia & Pakistan $^{15}$ & 82.8 & 11.5 & 1.9 \\
\hline
\end{tabular}


NPS Medicine Wise Learning is an Australian organisation which works in collaboration with many local health authorities. They provide independent, evidence based information on medicinal waste management. ${ }^{22}$ In UK the most comprehensive guidance is published by the Department of Health and pharmacies are obliged to accept back unwanted medicines from patients. The pharmacy as required by NHS England or the waste contractor sorts medicinal waste into solids (including ampoules and vials), liquids and aerosols. The local NHS England team makes arrangements for a waste contractor to collect the unused medicines from pharmacies at regular intervals. ${ }^{23}$

Table 2: Reasons to keep/discard/return unused medicines in different studies.

\begin{tabular}{|lll|}
\hline Country of the study & Reason for medication waste & Percentage (\%) from the total sample \\
\hline Ireland $^{\mathbf{8}}$ & Kept for later use & 68 \\
\hline Sweden $^{\mathbf{9}}$ & Environmental reasons & 50 \\
\hline \multirow{2}{*}{ Spain $^{\mathbf{1 0}}$} & Expiration of medicine & 28.4 \\
& Improvement of the patient & 24.9 \\
& Death of the patient & 20.8 \\
\hline \multirow{2}{*}{ Sweden $^{\mathbf{1 9}}$} & Expiration of medicine & \\
& Improvement of the patient & 75 \\
& Death of the patient & \\
\hline \multirow{2}{*}{ Kuwait $^{\mathbf{1 1}}$} & Change in the therapy & 49.8 \\
& Discontinuation/change by the doctor & 25.8 \\
\hline
\end{tabular}

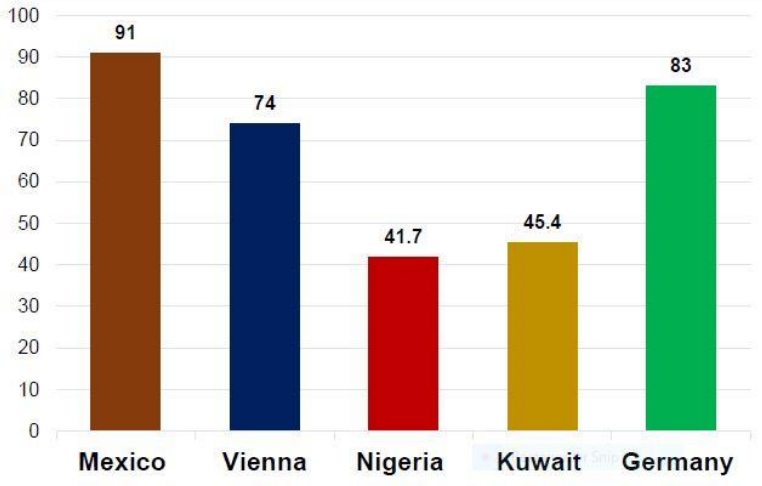

Figure 1: Prescription only medicines as a percentage from total returned medicines in different studies.

Medication waste management practices and the level of engagement with it can be used as a quality indicator of the health care system of the institution or the country. ${ }^{24}$ Unused prescription medicines cost the NHS across UK over $£ 300$ million every year. ${ }^{25}$ Re-use of unused medicines returned from patients is currently considered unethical in UK and these are usually destroyed by incineration. According to some studies, unused medicines had been returned in substantial quantities, and had considerable financial value, with many in a condition suitable for re-use. They have suggested reopening the debate on the potential for re-using these medicines in developing countries where medicines were not widely available and also within $\mathrm{UK}^{26}$

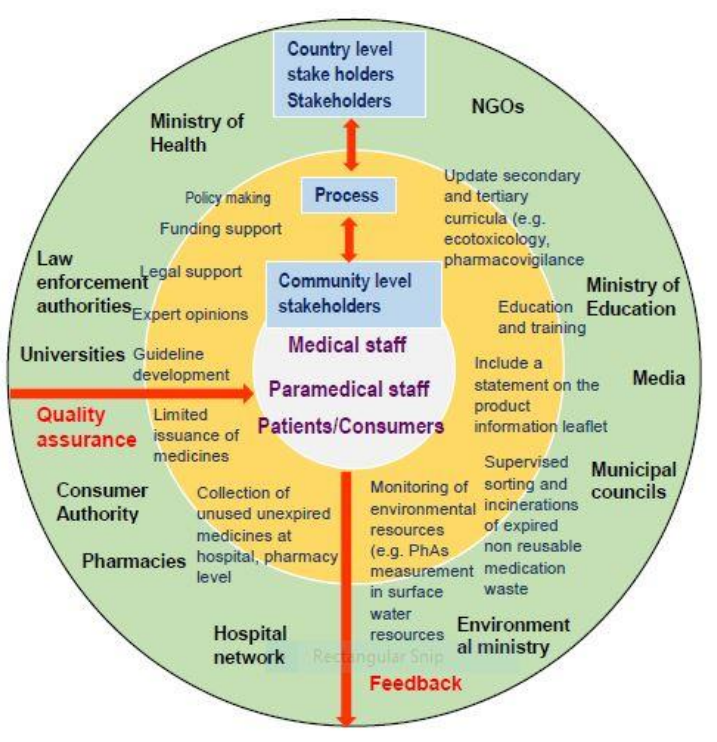

Figure 2: This wagon wheel represents a model for medical waste management in developing countries. Wheels indicate the need of sustainability and the layers indicates the systematic organisation and collaboration. Outer wheel represents the country level stakeholders including governmental and nongovernmental organisations. Middle wheel represents the process and the central wheel represents the community level stakeholders. Outward arrow indicates the feedback loop and the inward arrow indicates the quality assurance process which keeps the integrity of the system. 


\section{DISCUSSION}

This literature review showed that the overall status of medication waste management is not satisfactory worldwide except in few developed countries. Lack of established programmes may have largely contributed to the substandard nature of medication waste management in developing countries. Classes of medicines found in medication waste seem to correlate with common disease patterns in the community. Amount of medicines discarded as waste can be minimised by consumer education and prescribing and/or issuing the minimum required amount of medicines per person during a clinic visit. However, in some developing countries, over the counter medicines represented the major proportion of medication waste. This shows the unique nature of issues present in developing countries and the need of preliminary surveys to understand and quantify them. Although our review does not represent all countries under equal conditions, it will provide a good insight to understand the background of medication waste management globally. It seems medication waste management is a very much neglected field in most of the developing countries including in Asia.

Making national level policies by the governments and including them in the legislation is mandatory to establish successful programmes in developing countries. Because of political instability, trade-union pressure and pressure from multinational pharmaceutical companies, setting up of necessary laws and regulations is challenging to governments at times but is essential to get the maximum commitment from the stakeholders. Lack of funds and insufficient man power are going to be other challenges and lack of clear policy at the beginning will lead to failure of such programmes and further waste of funds and manpower.

International organisations such as WHO need to share their international experience and provide sufficient funds and support to establish sustainable medical waste management programmes in developing countries. Lack of efficiency in the government sector will be another barrier. Considering these unique challenges, abrupt transition toward an advanced system may be difficult in developing countries. Successful medical waste management programme needs collaboration with multiple governmental and non-governmental institutions. Preliminary situational surveys will definitely help to identify unique problems at institutional level and country level. Conducting pilot projects with proper feedback loops will help designing programmes customised to local needs.

We have summarised key elements for a medication waste management programme to suit with the infrastructure of developing countries (Figure 2) which can be used as an initial framework. However, this may need extensive modifications according to unique problems and available resources in each setting. Key governmental institutions which need to collaborate with each other are the Ministry of Health, Ministry of Environmental Protection, water board, municipal councils, law enforcement authorities, legal departments, universities, consumer authority, hospital and pharmacy network. The Ministry of Health should hold the leading role. A multidisciplinary committee should help in drafting policies and be responsible for the overall supervision of the programme. Universities and other academic institutions have the responsibility of providing expert opinions on medication waste management. Integration of this subject with undergraduate curricula will improve the understanding among junior doctors and pharmacists about the programme as well as their responsibilities.

Establishment of post graduate programmes such as ecotoxicology and pharmacovigilance will produce local experts in the subject. It is always good if the principles of medication waste management can be included in school curricula as well. Children will encourage their parents to comply with the programmes while they do so. All these steps will ensure sustainability of programmes. Separate systematic educational programmes need to be conducted for current stakeholders including doctors, pharmacists and consumers. Development of guidelines, publishing informative websites and including information on the disposal of pharmaceutical waste on labels of product containers will further streamline such programmes. Mass media has a key role to play on educating the general public. Multi-level and continuous education will boost knowledge and the right attitude among stakeholders which is essential for the success of medication waste management programmes.

Unused medicines can be divided into two categories as expired and non-expired. Expired medicines need to be sorted out separately and incinerated by municipal authorities. But the rural population may not be able to access municipals and therefore other local authorities may need to take the responsibility. Although lack of man power will be an issue, defining the role for each stakeholder group will minimise negative consequences. Offering the consumers with discounts for their purchases based on returned medicines as well as initiatives such as 'National take back day for medicines' will encourage general public to engage more and more with these programmes. Periodic feedback via surveys and quality assurance audits will help to understand emerging problems and to improve systems on a regular basis.

Currently, we are conducting a preliminary survey on knowledge, attitudes and practices of medication waste management among island wide pharmacies in Sri Lanka. We hope to open up a discussion on this in our country very soon. We believe developing countries should join the on-going international forum on medication waste management. This short communication will be an eye opener for the academic key opinion leaders in developing countries to initiate medical waste management programmes in their countries. 
In conclusion, international level policy and funding support, national level policy and unbiased financial allocations, institutional level comprehensive programmes according to local requirements and most importantly the public support will make medication waste management programme a success. The initial model for a medication waste management that we propose may need extensive modifications through a continuous assessment and a feedback loop. Support from mass media and focused educational programmes will make it easier to reach the general public and keep them engaged with these programmes ensuring sustainability.

Funding: No funding sources

Conflict of interest: None declared

Ethical approval: Not required

\section{REFERENCES}

1. Household Medication Waste Disposal, 2015. Available at http://www.calrecycle.ca.gov/homehazwaste/ Medications/household.htm. Accessed Sep 152016.

2. Bronstein AC, Spyker DA, Cantilena LR, Green JL, Rumack BH, Heard SE, et al. Annual Report of the American Association of Poison Control Centers' National Poison Data System (NPDS). 25th Annual Report. Clin Toxicol. (Phila) 2008;46:927-1057.

3. Fent K, Weston AA, Caminada D. Ecotoxicology of human pharmaceuticals. Aquat. Toxicol. 2006;76:12259.

4. Heberer T, Heberer T. Occurrence, fate, and removal of pharmaceutical residues in the aquatic environment: a review of recent research data. Toxicol Lett. 2002;131:5-17.

5. Jobling S, Williams R, Johnson A, Taylor A, GrossSorokin M, Nolan M, et al. Predicted exposures to steroid estrogens in U.K. Rivers correlate with widespread sexual disruption in wild fish populations. Environ Health Perspect. 2006;114:32-9.

6. Tischler L, Buzby M, Finan DS, Cunningham VL. Landfill disposal of unused medicines reduces surface water releases. Integr. Environ. Assess. Manag. 2013;9:142-54.

7. Bound JP, Voulvoulis N. Household disposal of pharmaceuticals as a pathway for aquatic contamination in the United kingdom. Environ. Health Perspect. 2005;113:1705-11.

8. Vellinga A, Cormican S, Driscoll J, Furey M, O’Sullivan M, Cormican M. Public practice regarding disposal of unused medicines in Ireland. Sci. Total Environ. 2014;478:98-102.

9. Persson M, Sabelström E, Gunnarsson B. Handling of unused prescription drugs-knowledge, behaviour and attitude among Swedish people. Environ Int. 2009;35:771-4

10. Coma A, Modamio P, Lastra CF, Bouvy ML, Mariño EL. Returned medicines in community pharmacies of Barcelona, Spain. Pharm. World Sci. 2008;30:272-7.
11. Abahussain EA, Ball DE, Matowe WC. Practice and opinion towards disposal of unused medication in Kuwait. Med Princ Pract. 2006;15:352-7.

12. Kuspis DA, Krenzelok EP. What happens to expired medications? A survey of community medication disposal. Vet Hum Toxicol. 1996;38:48-9.

13. Sasu S, Kümmerer K, Kranert M. Assessment of pharmaceutical waste management at selected hospitals and homes in Ghana. Waste Manag Res. 2012;30:62530 .

14. Auta A, Omale S, Shalkur D, Abiodun AH. Unused medicines in Nigerian households: Types and disposal practices. J Pharmacol Pharmacother. 2011;2:195-6.

15. Ahmed A, Mushtaq N, Tariq M, Durrani M, Akhtar S, Arif M, et al. Disposal practices of unused and expired pharmaceuticals in karachi and theirimpact on health and environment. JUMDC. 2013;4(2):42-8.

16. Gracia-Vásquez SL, Ramírez-Lara E, Camacho-Mora IA, Cantú-Cárdenas LG, Gracia-Vásquez YA, EsquivelFerriño PC, et al. An analysis of unused and expired medications in Mexican households. Int J Clin Pharm. 2015;37:121-6.

17. Vogler S, Leopold C, Zuidberg C, Habl C. Medicines discarded in household garbage: analysis of a pharmaceutical waste sample in Vienna. J. Pharm. Policy Pract. 2014;7:6.

18. Bronder E, Klimpel A. Unused drugs returned to the pharmacy--new data. Int $\mathrm{J}$ Clin Pharmacol Ther. 2001;39:480-3.

19. Ekedahl ABE. Reasons why medicines are returned to Swedish pharmacies unused. Pharm World Sci. 2006;28:352-8.

20. National Take-Back Initiative 2015. Available at http://www.deadiversion.usdoj.gov/drug_disposal/takeb ack/. Accessed 15 Sep 2016.

21. U. S. Food and Drug Administration - Consumer updates 2016. Available at http://www.fda.gov/ForConsumers/ConsumerUpdates/u cm101653.html. Accessed 15 Sep 2016.

22. Unused medicines - what to do with them? 2015. Available at http://www.nps.org.au/topics/how-to-bemedicinewise/managing-your-medicines/unusedmedicines. Accessed 15 Sep 2016.

23. Disposal of Unwanted Medicines UK 2015. Available at http://psnc.org.uk/services-commissioning/essentialservices/disposal-of-unwanted-medicines/. Accessed 15 Sep 2016.

24. Thormodsen M, Fonneløp H, Rytter E, Tørisen HM. Returned medicines as quality indicator for pharmacotherapy-what is left? Tidsskr Prakt Med. 1997;117:3517-20.

25. Did You Know? Wasted medicines waste money 2015. Available at http://www.medicinewaste.com/help. Accessed 15 Sep 2016.

26. Mackridge AJ, Marriott JF. Returned medicines: waste or a wasted opportunity? J Public Health (Oxf). 2007;29:258-62.

Cite this article as: Bataduwaarachchi VR,

Weeraratne CL. Global medication waste

management practices: challenges and opportunities in developing countries. Int J Basic Clin Pharmacol 2016;5:2290-4. 